\title{
Plastid genome size and heterogeneous base composition of nuclear DNA from Ochrosphaera neapolitana (Prymnesiophyta)
}

\author{
Alberto G. SÁez ${ }^{1,2 *}$, Heinz Engel ${ }^{\dagger}$ Linda K. Medlin ${ }^{2}$ and Volker A.R. Huss ${ }^{1}$ \\ ${ }^{1}$ Institut für Botanik und Pharmazeutische Biologie der Universität, Staudtstr. 5, D-91058 Erlangen, Germany \\ ${ }^{2}$ Alfred Wegener Institute for Polar and Marine Biology, Am Handelshafen 12, D-27570 Bremerhaven, Germany
}

\begin{abstract}
A.G. SÁez, H. Engel, L.K. Meduin \& V.A.R. Huss. 2001. Plastid genome size and heterogeneous base composition of nuclear DNA from Ochrosphaera neapolitana (Prymnesiophyta). Phycologia 40: 147-152.

We have studied the plastid genome of Ochrosphaera neapolitana (Hymenomonadaceae, Prymnesiophyta), a member of the chlorophyll a + c-containing algae. Total DNA from O. neapolitana was fractionated in a $\mathrm{CsCl}$ density gradient and the 'lighter' upper band (which is typically of plastid origin) was unusually abundant relative to the 'heavier' nuclear one. Denaturation and renaturation experiments done with DNA isolated from the upper band showed that it had a base composition of $43.6 \mathrm{~mol} \% \mathrm{G}+\mathrm{C}$ (molar fraction of guanosine plus cytosine), compared to $60.5 \mathrm{~mol} \% \mathrm{G}+\mathrm{C}$ in the lower band, and that it lacked a substantial fraction of repetitive sequences; this DNA had a size of $c$. $10 \mathrm{Mb}$, which is more than an order of magnitude larger than has been reported for any plastid genome. Using Pulse Field Gel Electrophoresis (PFGE) of total DNA, we resolved a plastid genome size of approximately $165 \mathrm{~kb}$ for $O$. neapolitana. Although this is within the range reported for other plastid genomes, there is an increase of about $40 \mathrm{~kb}$ compared to related algae. Using the upper band from the $\mathrm{CsCl}$ gradient as a probe for the PFGE blots, we showed that this upper band is apparently a mixture of nuclear DNA with a small fraction of plastid DNA. The nuclear genome of Ochrosphaera neapolitana thus appears to have a distinctive heterogeneity in $\mathrm{G}+\mathrm{C}$ content, with two DNA types differing by $c$. $17 \mathrm{~mol} \%$.
\end{abstract}

\section{INTRODUCTION}

The endosymbiotic hypothesis of plastid evolution maintains that chloroplasts were originally acquired by eukaryotic heterotrophs through the endocytotic capture of photosynthetic prokaryotes and their subsequent conversion into organelles (Schimper 1883; Mereschkowsky 1905; Raven 1970; Margulis 1981). The plastids of rhodophyte, chlorophyte and glaucocystophyte algae and higher plants have plastids that are surrounded by only two membranes and are therefore assumed to have resulted from a primary endosymbiotic event, in which a eukaryotic host engulfed a prokaryotic cell. The host organisms associated with the primary endosymbioses have been proposed to have arisen as independent plastid-bearing lineages within the crown group radiation of the eukaryotes (Bhattacharya \& Medlin 1995). However, there is increasing evidence for a monophyletic origin of the rhodophyte and chlorophyte lineages, and possibly also the glaucocystophyte lineage (Burger et al. 1999; Moreira et al. 2000). The genomes of these plastids are typically $89-292 \mathrm{~kb}$ in size and the smaller ones among them usually lack an inverted repeat unit of the ribosomal rRNA genes (Sugiura et al. 1998).

Other algae have plastids surrounded by three or four membranes and these are hypothesized to have arisen through secondary endosymbiotic events, in which a heterotrophic eukaryote host engulfed and reduced a photosynthetic eukaryote cell to a plastid. The additional outer membranes surrounding the plastid reflect its secondary origin, representing the host vacuole membrane and the plasmalemma of the eukaryotic endosymbiont (Gibbs 1993). Algae resulting from secondary endosymbioses include the euglenophytes and chlorarachniophytes, which contain chlorophylls $a$ and $b$, as well as the heterokont chromophytes, haptophytes, dinoflagellates and cryptophytes, most of which contain chlorophylls $a$ and $c$ (Gibbs 1978, 1981; Cavalier-Smith 1989; Jeffrey 1989; Rowan 1989; Kowallik 1992; Valentin et al. 1992). These plastids are $118-154 \mathrm{~kb}$ in size and have an inverted repeat of the ribosomal RNA genes. Other differences between primary and secondary endosymbiotic lines also include the types and numbers of genes transferred to the nucleus (Martin et al. 1998).
There is continued interest in the evolution of plastids, with recent studies documenting the evolution of the highly reduced plastids of parasitic Apicomplexa, such as Plasmodium (McFadden \& Waller 1997), and the remarkable diversity of plastids in the dinoflagellates, including some that represent tertiary endosymbioses (Tengs et al. 2000) and others that posses individual ring structures (replicons) for each gene (Zhang et al. 1999). In addition, the timing of endosymbioses events (Medlin et al. 1997) and the numbers and types of plastid genes transferred to the nucleus (Martin et al. 1998) have been studied. Here we study the base composition and size of the plastid genome of the chlorophyll a + c-containing alga Ochrosphaera neapolitana Schussnig. Although the group of algae to which Ochrosphaera belongs - the coccolithophorids - is a very large and ecologically important one, its plastid genomes have been poorly investigated.

\section{MATERIAL AND METHODS}

\section{Cultures}

Ochrosphaera neapolitana HAP13 and Pavlova lutheri (Droop) J.C. Green (Pavlovales, Prymnesiophyta) HAP44 (=PLY75) were obtained from the Algobank collection of the University of Caen, France (http: //www.unicaen.fr/unicaen/ufr/ibba/lbbm/algobank/). Both species were grown in approximately $500 \mathrm{ml}$ (for PFGE) or c. 10 litres (for $\mathrm{CsCl}$ gradients) of ES-Tris II medium (Cosson 1987), aerated by bubbling (approximately one bubble per second; $0.2 \% \mathrm{CO}_{2}$ in air bubbled through media). Cells were harvested during the exponential growth phase and centrifuged at $2500 \times \mathrm{g}$ for $5 \mathrm{~min}$ at $4^{\circ} \mathrm{C}$. At this speed we noticed that most of the algae sedimented to the bottom of the tubes, whereas most of the bacteria remained in the supernatant. We washed the cells in $100 \mathrm{mM}$ Tris- $\mathrm{HCl} \mathrm{pH} 7.5,100 \mathrm{mM} \mathrm{NaCl}$ and $50 \mathrm{mM}$ EDTA (at $4^{\circ} \mathrm{C}$ ) by resuspending the cells in this buffer and centrifuging under the same conditions as above. We performed three washes, after which we observed almost no bacteria, either in the supernatant or among the collected algae. Cultures of Chlorella sorokiniana Shih. \& Krauss (Trebouxiophyceae, Chlorophyta) and Escherichia coli were grown as described in Huss et al. (1986).

\footnotetext{
* Corresponding author: (alberto@awi-bremerhaven.de).

$\dagger$ Present address: Fa. Viramed GmbH, Behringstr. 11, D-82152 Planegg,

Germany
} 


\section{DNA extraction and $\mathrm{CsCl}$ gradients}

DNA was extracted and purified according to Huss et al. (1986). Reference algae and bacteria were homogenized with glass beads and the cell extracts separated from the beads by washing with $10 \mathrm{mM}$ Tris- $\mathrm{HCl}, 1 \mathrm{mM}$ EDTA $\mathrm{pH} 8.0$ and suction through a coarse sintered filter. Lysis of Ochrosphaera cells could be achieved by adding distilled water, leaving most of the remaining contaminating bacteria unaffected. DNA was purified by a modification of Marmur's (1961) method, using CTAB, RNAse A (Serva), and proteinase K (Merck) for the removal of polysaccharides (Darby et al. 1970), RNA, and proteins, respectively. $\mathrm{CsCl}$ density gradient centrifugation was performed for $40 \mathrm{~h}$ at $42,000 \mathrm{rpm}$ and $20^{\circ} \mathrm{C}$ in a VTi 50 rotor of a Beckman L8-60M ultracentrifuge, as described by Huss et al. (1988). Fifty microlitres of bisbenzimide (Hoechst dye 33258) per mg DNA were added for better separation of AT- and GC-rich DNA bands (Müller \& Gautier 1975) and visualization in UV-light at $312 \mathrm{~nm}$. Dye removal was effected by several extractions of the recovered DNA with $\mathrm{CsCl}$-saturated isopropanol. To remove $\mathrm{CsCl}$, the DNA solutions were dialysed twice against large volumes of standard saline citrate (SSC: $0.15 \mathrm{M} \mathrm{NaCl}$, $0.015 \mathrm{M}$ trisodium citrate $\mathrm{pH}$ 7.0). If necessary, DNA was concentrated in dialysis tubes over dry saccharose with subsequent dialysis.

\section{DNA reassociation kinetics and $c_{0} t$ analyses}

DNA reassociation was followed optically in a Gilford Response ${ }^{\mathrm{TM}}$ spectrophotometer as described by Britten et al. (1974). The conditions and parameters used for the reassociation kinetics and $\mathrm{c}_{0} \mathrm{t}$ analyses, as well as for second order rate plots (Wetmur \& Davidson 1968), were as described by Dörr \& Huss (1990).

\section{Pulse Field Gel Electrophoresis (PFGE)}

We followed mainly the method of Cole \& Williams (1988) for the preparation of the PFGE plugs (cells embedded in agarose). One volume $(0.5 \mathrm{ml})$ of $2 \%$ low melting point agarose (FMC) in $90 \mathrm{mM}$ Tris-borate, $2 \mathrm{mM}$ EDTA $\mathrm{pH} 8.0$ (TBE) at $40^{\circ} \mathrm{C}$ was mixed with the same volume of harvested algae using a $1 \mathrm{ml}$ syringe. The mixture was cooled on ice for $5 \mathrm{~min}$ within the syringe. The agarose plug was then removed from the syringe into $30 \mathrm{ml}$ of $500 \mathrm{mM}$ EDTA, $10 \mathrm{mM}$ Tris$\mathrm{HCl} \mathrm{pH} \mathrm{7.5,} 1 \%$ Sarcosyl and $1 \mathrm{mg} \mathrm{ml}^{-1}$ proteinase $\mathrm{K}$ (lysis buffer) at $50{ }^{\circ} \mathrm{C}$ in a horizontally rotating tube and incubated overnight. Then the buffer was discarded and a second wash performed under the same conditions. The agarose plugs were stored at $4^{\circ} \mathrm{C}$ in fresh lysis buffer lacking proteinase $\mathrm{K}$. Approximately $2 \mathrm{~mm}$ of a cross-section of these plugs were inserted into the wells of a $1 \%$ agarose gel used for PFGE. Electrophoresis conditions in $0.5 \times$ TBE buffer were $2 \mathrm{~h}$ at 140 volts with a constant field, followed by $36 \mathrm{~h}$ at the same voltage but with periodic rotations of $120^{\circ}$ and increasing electrical pulse times from 60 to $120 \mathrm{~s}$ between rotations (initial and final pulses respectively). After $26 \mathrm{~h}$, the run was interrupted to obtain a better resolution of the plastid genomes (in previous runs we observed that shorter runs improved the resolution).

\section{Southern blots}

A standard protocol from Ausubel et al. (1992: alkaline method) was followed for obtaining the Southern blots. Positively-charged nylon membranes were used (Boehringer, Mannheim). The prehybridization lasted for $2 \mathrm{~h}$ in $7 \%$ SDS, $500 \mathrm{mM}$ sodium phosphate, $1 \mathrm{mM}$ EDTA, $\mathrm{pH}$ 7.2 , at $65^{\circ} \mathrm{C}$. Hybridization to the labelled probes was done under the same conditions for approximately $15 \mathrm{~h}$. Blots were washed three times in twofold concentrated SSC, $0.1 \% \mathrm{SDS}$, at $65^{\circ} \mathrm{C}$ for $20 \mathrm{~min}$.

\section{RESULTS}

We used $\mathrm{CsCl}$ gradient centrifugation to study the plastid and nuclear genomes of $O$. neapolitana. Total DNA extracted from the algae was centrifuged in a $\mathrm{CsCl}$ solution at high speed. Because AT pairs are less dense than GC pairs in double-stranded DNA, and because plastid genomes are usually less GC-rich than nuclear genomes, $\mathrm{CsCl}$ centrifugation separates a light plastid fraction from a heavier nuclear fraction (Ausubel et al. 1992). As expected, $\mathrm{CsCl}$ centrifugation produced two distinct bands of DNA in O. neapolitana. Typically, plastid DNA accounts for about 10\% of the total DNA (Bastia et al. 1971; Coleman \& Goff 1991) but, surprisingly, in O. neapolitana the lighter upper band was almost as prominent as the heavier one. Thermal denaturation of these two DNA species (De Ley 1970) showed a base composition of $43.6 \mathrm{~mol} \% \mathrm{G}+\mathrm{C}$ for the lighter band (hereafter designated L-DNA) and $60.5 \mathrm{~mol} \% \mathrm{G}+\mathrm{C}$ for the heavier band. The purified L-DNA was then used in DNA reassociation analyses, in which the kinetics of DNA renaturation can be studied (Britten et al. 1974). These analyses offer an overall assessment of the proportion of single vs repetitive copy sequences, and allow a rough estimate of DNA length. Using Chlorella sorokiniana and Escherichia coli as controls, we found that isolated L-DNA from $O$. neapolitana had a size greater than $10 \mathrm{Mb}$ (Fig. 1A). This would be at least an order of magnitude larger than has been described for any plastid genome (which range from 89 to $292 \mathrm{~kb}$ : Sugiura et al. 1998). Moreover, a second-order rate plot of the reassociation data showed that the L-DNA of $O$. neapolitana was almost completely composed of single copy genes (Fig. 1B). These results suggest either that $O$. neapolitana possesses an exceptionally large plastid genome, or that the L-DNA is a mixture of plastid and mainly nuclear DNA, in which case the plastid genome of $O$. neapolitana might be of normal size. These two hypotheses were tested.

The most straightforward technique to resolve the size of any chromosome is PFGE. This is an agarose-gel electrophoresis with periodical changes in the direction, strength, and pulse time of its electrical field, allowing separation of DNA fragments larger than $50 \mathrm{~kb}$ (Cantor et al. 1988). Total DNA from O. neapolitana and Pavlova lutheri was separated by PFGE, transferred to a nylon membrane, and probed with ${ }^{32} \mathrm{P}$-labelled DNA fragments of three typical plastid genes isolated, either from $O$. neapolitana alone (ATPase B and 23S rDNA), or from both $O$. neapolitana and $P$. lutheri $(r b c \mathrm{~L})$. Pavlova lutheri was included in our experiments because it represents a closely related evolutionary lineage within the Prymnesiophyta (Edvardsen et al. 2000) and because its plastid genome size (115 kb, i.e. well within the normal range) has been previously reported using PFGE as well (Scaramuzzi et al. 1992). The three probes revealed DNA bands of approximately $165 \mathrm{~kb}$ for $O$. neapolitana (Fig. 2) and of $120 \mathrm{~kb}$ for P. lutheri. The ATPaseB probe from $O$. neapolitana did not produce a signal with $P$. lutheri DNA under the conditions specified in the Material and Methods (Fig. 2), although a $120 \mathrm{~kb}$ band was visible after a very prolonged exposure (not shown). No larger chromosomes hybridized with the 23S rDNA and ATPase B probes (not even with a tenfold greater exposure time). However, the $r b c \mathrm{~L}$ probe reacted with two large chromosomes $(>1120 \mathrm{~kb})$ from $O$. neapolitana, in what might be a nonspecific hybridization. A nuclear $18 \mathrm{~S}$ rDNA probe (isolated via PCR from both species) hybridized to several chromosomes larger than $1 \mathrm{Mb}$ in the two algae (Fig. 2). In $P$. lutheri, a fragment of approximately $70 \mathrm{~kb}$ appeared, which was most likely a degradation product. An additional PFGE blot was incubated with total L-DNA from $O$. neapolitana as a probe. Because of the many DNA fragments contained in this probe, a very intense signal was observed in the autoradiographs. In X-ray films exposed for a short time it was possible to see that most of the signal originates from chromosomes larger than $1.12 \mathrm{Mb}$ (Fig. 2).

\section{DISCUSSION}

The PFGE results indicate that the AT-rich L-DNA from $O$. neapolitana is composed largely of a nuclear DNA, but also a small amount of plastid DNA. We know that L-DNA contains plastid sequences because specific genes from the plastid genome, such as the rRNA- and the atp gene clusters, were isolated and characterized from $O$. neapolitana L-DNA (Giovannoni et al. 1992; Tietze 1996). The nuclear genome is heterogeneous with respect to its base composition in many taxa, e.g. insects (Carulli et al. 1993), plants (Barakat et al. 1998) and yeast 
A)

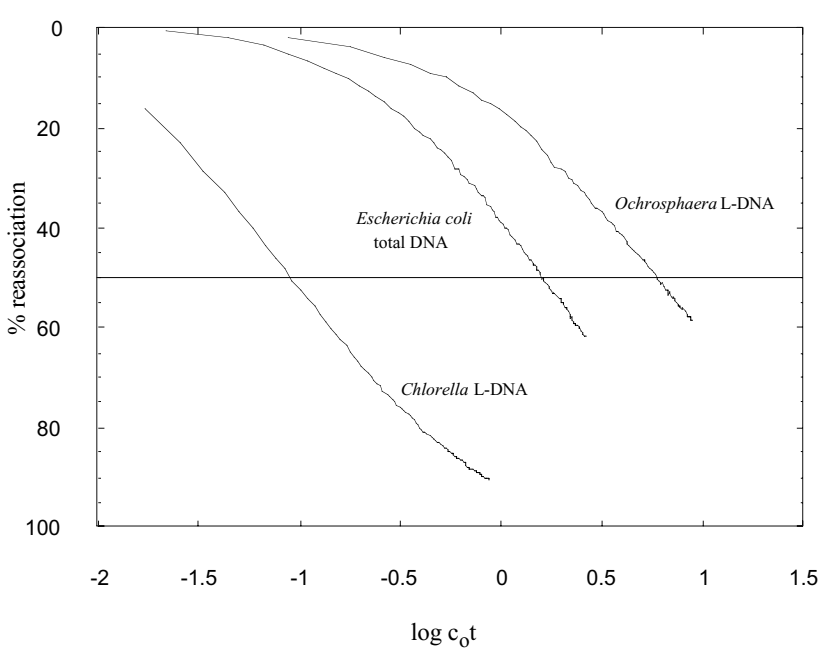

B)

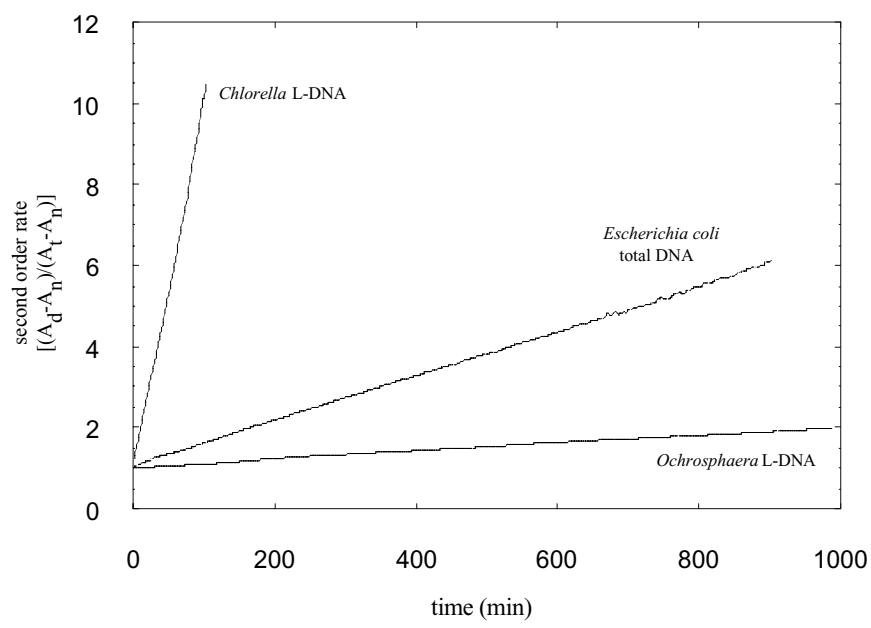

Fig. 1. DNA renaturation kinetics of L-DNA from Ochrosphaera neapolitana and Chlorella sorokiniana, and of total DNA from Escherichia coli.

(A) Log c t diagram (Britten et al. 1974): the fraction of reassociated single stranded DNA is plotted against the logarithm of the product of DNA concentration and time. The $\log \mathrm{ct}$ values at $50 \%$ reassociation (straight horizontal line) were taken to calculate the kinetic complexities as $0.25 \mathrm{Mb}$ (Chlorella) and $15.9 \mathrm{Mb}(O$. neapolitana) with $E$. coli as a reference (4.2 Mb; Cairns 1963).

(B) Second-order rate plot (Wetmur \& Davidson 1968; data are taken from Fig. 1A): straight lines indicate the absence of significant amounts of repetitive sequences. For details, see Dörr \& Huss (1990).

(Bradnam et al. 1999), and the range of GC content is similarly wide as in $O$. neapolitana (17\%). One possible explanation is that pervasive selective constraints are acting upon coding regions by forcing them to maintain a distinct base composition relative to other, more freely evolving regions, whose GC ratio is determined mainly by mutational bias ( $\mathrm{Li}$ 1997). A second possibility, not mutually exclusive with respect to the previous, is that mutational properties vary among chromosomes or chromosome segments; such a phenomenon has recently been confirmed for mammals (Matassi et al. 1999). What appears to be exceptional about the nuclear genome of $O$. neapolitana is the markedly 'bimodal' heterogeneity of its DNA base composition, with two clearly distinct types of DNA sequences. Where $\mathrm{CsCl}$ gradients have been obtained from other species, a single band of nuclear DNA has been observed, even though the overall GC range may be similar to that found in $O$. neapolitana. For example, it has been suggested that most genes cluster within a small fraction of the GC range in maize (1-2\%: Carels et al. 1995), barley and rice $(0.8$

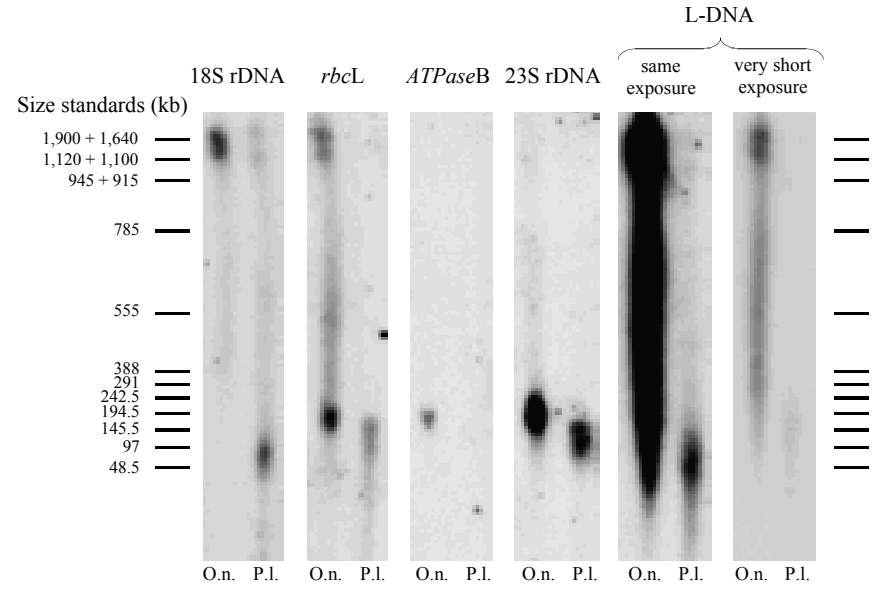

Fig. 2. Southern blot analysis of total DNA from Ochrosphaera neapolitana (O.n.) and Pavlova lutheri (P.1.) to identify the size of their plastid genomes. Total DNA from both species was separated by PFGE. The different probes used are indicated on the top (see text). The blot in the far right lane was exposed at room temperature (instead of $-70^{\circ} \mathrm{C}$ ) and for only one fifth of the time compared to the others.

and $1.6 \%$, respectively: Barakat et al. 1997), and Arabidopsis thaliana (8\%: Barakat et al. 1998); however, $\mathrm{CsCl}$ profiles in these species are continuous and exhibit only one predominant peak. The fact that we obtain, instead, two clearly distinct bands suggests that there is a strong compartmentalization of the GC ratio among chromosomes. This, in turn, favours the idea expressed above that chromosome-specific mutational bias is responsible for the GC heterogeneity.

There is a third, highly speculative possibility, which could explain both the heterogeneity in GC composition and its compartmentalization: a massive, recent lateral gene transfer from another organism. Sequencing genome projects on several microbes are revealing that horizontal or lateral gene transfer is much more frequent than had previously been thought (Fraser et al. 2000). It has been suggested, for example, that approximately $25 \%$ of the genes of two bacteria have been transferred from archaebacteria, based on their higher similarity to archaeal rather than to bacterial genes (Aravind et al. 1998).

We discard alternative explanations based on two sources of potential artifacts: DNA methylation and significative amounts of bacterial DNA in our preparations. Methylation has been shown to have no significant effect on the melting point of DNA (Huss \& Jahnke 1994), which was the parameter used in calculating the base composition of the upper and the lower DNA bands in the $\mathrm{CsCl}$ gradients. Although our cultures were not axenic, the algae taken for DNA extraction did not contain substantial amounts of bacteria (see Methods). We carried out two experiments to verify this. First, we grew the bacteria isolated from the supernatant of the $O$. neapolitana culture. Their genome size was $2.55 \times 10^{9} \mathrm{Da}$, as compared to $6.92 \times 10^{9} \mathrm{Da}$ of $O$. neapolitana L-DNA, both determined via reassociation kinetics (data not shown). And second, we could amplify the plastid 16S rRNA gene from $O$. neapolitana L-DNA by PCR, whereas no bacterial $16 \mathrm{~S}$ rRNA genes were detected in this way. We thus conclude that bacterial DNA, if present at all in $O$. neapolitana L-DNA, could not significantly influence our results.

The distinctly heterogeneous GC composition may be a feature shared by other prymnesiophytes, perhaps excluding members of the Pavlovophyceae (Cavalier-Smith) J.C. Green \& Medlin, since the sole representative of this class that we studied - Pavlova lutheri - showed the standard eukaryote pattern (data not shown). We have examined another coccolithophorid of the same family as O. neapolitana, Hymenomonas globosa (Magne) Gayral \& Fresnel (Hymenomonadaceae, Prymnesiophyta), and this showed a pattern very similar to $O$. neapolitana: DNAs isolated from $\mathrm{CsCl}$ gradients revealed 36 and $58 \mathrm{~mol} \% \mathrm{GC}$ for the light and heavy DNA bands, respectively, with sizes of approximately $17 \mathrm{Mb}$ for L-DNA as indicated by reassociation experiments (data not shown). It would be worthwhile to extend these studies to other coccolithophorids and find out if the same 
'bimodal' heterogeneity of GC content is present throughout.

Our PFGE results reveal a plastid genome size in $O$. neapolitana of approximately $165 \mathrm{~kb}$ and confirm the size reported for P. lutheri (c. $120 \mathrm{~kb}$ vs $115 \mathrm{~kb}$ determined by Scaramuzzi et al. 1992). Thus, O. neapolitana has a significantly larger plastid genome than other chlorophyll a $+\mathrm{c}$-containing algae. It is approximately $45-50 \mathrm{~kb}$ larger than the plastid genomes of $P$. lutheri or the diatom Odontella sinensis $(119,704 \mathrm{bp}) ; O$. sinensis is the most closely related alga from which the whole plastid genome has been completely sequenced (Kowallik et al. 1995). The plastid genome of the chlorophyll a $+\mathrm{c}$ containing cryptophyte Guillardia theta Hill \& Wetherbee (Cryptomonadaceae, Cryptophyta) also falls in the same range $(121,524$ bp: Douglas \& Penny 1999). Ochrosphaera neapolitana is in fact more similar in this respect to red algae, the proposed ancestors of chlorophyll a $+\mathrm{c}-$ containing plastids (Valentin \& Zetsche 1990): Cyanidium caldarium Geitler (Bangiophyceae, Rhodophyta) and Porphyra purpurea (Roth) C. Agardh (Bangiophyceae, Rhodophyta) have plastid genomes of 164,921 bp and 191,028 bp, respectively (GenBank accessions AF022186 and U38804). However, given the smaller plastid genome sizes of Pavlova lutheri, Odontella sinensis and $G$. theta, the three closest relatives of Ochrosphaera neapolitana whose plastid genomes have been characterized for size so far, we would predict that the larger plastid genome in $O$. neapolitana is a derived character, and not an ancestral one shared with red algae. It would be interesting to know if the plastid genome from $O$. neapolitana contains additional genes not present in other chlorophyll a $+\mathrm{c}$-containing algae. However, if the larger plastid genome is a derived characteristic, it is more likely that the extra DNA in O. neapolitana is 'selfish' or 'junk' DNA (e.g. transposons).

\section{ACKNOWLEDGEMENTS}

We thank Chantal Billard for sending the strains studied in this report and for her advice in growing them. We also thank Klaus Valentin, David G. Mann and two anonymous reviewers for many useful comments or corrections to the manuscript. And finally to Friedel Hinz for helping us to take the picture in Fig. 2. This work was funded by the EU CODENET project, ERBFMXCT-970113.

\section{REFERENCES}

Aravind L., Tatusov R.L., Wolf Y.I., Walker D.R. \& Koonin E.V. 1998 Evidence for massive gene exchange between archaeal and bacterial hyperthermophiles. Trends in Genetics 14: 442-444.

Ausubel F.M., Brent R., Kingston R.E., Moore D.D., Seidman J.G., Smith J.A \& Struhl K. 1992. Current protocols in molecular biology. John Wiley \& Sons, New York. Chapter 2.

Barakat A., Carels N. \& Bernardi G. 1997. The distribution of genes in the genome of Gramineae. Proceedings of the National Academy of Sciences of the United States of America 94: 6857-6861.

Barakat A., Matassi G. \& Bernardi G. 1998. Distribution of genes in the genome of Arabidopsis thaliana and its implications for the genome organization of plants. Proceedings of the National Academy of Sciences of the United States of America 95: 10044-10049.

Bastia D., Chiang K.-S., Swift H. \& Siersma P. 1971. Heterogeneity, complexity, and repetition of the chloroplast DNA of Chlamydomonas reinhardtii. Proceedings of the National Academy of Sciences of the United States of America 68: 1157-1161.

Bhattacharya D. \& Medlin L. 1995. The phylogeny of plastids: A review based on comparison of small subunit ribosomal RNA coding regions. Journal of Phycology 31: 489-498.

Bradnam K.R., Seoighe C., Sharp P.M. \& Wolfe K.H. 1999. G + C conten variation along and among Saccharomyces cerevisiae chromosomes. Molecular Biology and Evolution 16: 666-675.

Britten R.J., Graham D.E. \& Neufeld B.R. 1974. Analysis of repeating DNA sequences by reassociation. Methods in Enzymology 29E: 363-406.

Burger G., Saint-Louis D., Gray M.W. \& Lang B.F. 1999. Complete sequence of the mitochondrial DNA of the red alga Porphyra purpurea: cyanobacterial introns and shared ancestry of red and green algae. Plant
Cell 11: 1675-1694.

CAirns J. 1963. The chromosome of E. coli. Cold Spring Harbor Symposia on Quantitative Biology 28: 43-46.

Cantor C.R., Sмith C.L. \& Mathew M.K. 1988. Pulsed-field gel electrophoresis of very large DNA molecules. Annual Review of Biophysics and Biophysical Chemistry 17: 287-304.

Carels N., Barakat A. \& Bernardi G. 1995. The gene distribution of the maize genome. Proceedings of the National Academy of Sciences of the United States of America 92: 11057-11060.

Carulli J.P., Krane D.E., Hartl D.L. \& Ochman H. 1993. Compositional heterogeneity and patterns of molecular evolution in the Drosophila genome. Genetics 134: 837-845.

CAvalier-Smith T. 1989. The Chromophyta, past and present. In: The chromophyte algae: problems and perspectives (Ed. by J.C. Green, B.S.C. Leadbeater \& W.L. Diver), pp. 1-12. Clarendon Press, Oxford.

Cole R.A. \& Williams K.L. 1988. Insertion of transformation vector DNA into different chromosomal sites of Dictyostelium discoideum as determined by pulse field electrophoresis. Nucleic Acids Research 16: 4891-4902.

Coleman A.W. \& GofF L.J. 1991. DNA analysis of eukaryotic algal species. Journal of Phycology 27: 463-473.

Cosson J. 1987. Croissance des sporophytes issus d'hybridations interspécifiques et intergénériques chez les Laminaires. Cryptogamie, Algologie 8: 61-72.

Darby G.K., Jones A.S., Kennedy J.F. \& Walker R.T. 1970. Isolation and analysis of the nucleic acids and polysaccharides from Clostridium welchii. Journal of Bacteriology 103: 159-165.

De LeY J. 1970. Reexamination of the association between melting point, buoyant density, and chemical base composition of deoxyribonucleic acid. Journal of Bacteriology 101: 738-754.

DöRR R. \& Huss V.A.R. 1990. Characterization of nuclear DNA in 12 species of Chlorella (Chlorococcales, Chlorophyta) by DNA reassociation. BioSystems 24: 145-155.

Douglas S.E. \& Penny S.L. 1999. The plastid genome of the cryptophyte alga, Guillardia theta: complete sequence and conserved synteny groups confirm its common ancestry with red algae. Journal of Molecular Evolution 48: 236-244.

Edvardsen B., Eikrem W., Green J.C., Andersen R., Moon-van der Staay S.Y. \& MeduIn L.K. 2000. Phylogenetic reconstructions of the Haptophyta inferred from $18 \mathrm{~S}$ ribosomal DNA sequences and available morphological data. Phycologia 39: 19-35.

Fraser C.M., Eisen J.A. \& Salzberg S.L. 2000. Microbial genome sequencing. Nature 406: 799-803.

GiBBS S.P. 1978. The chloroplasts of Euglena may have evolved from symbiotic green algae. Canadian Journal of Botany 56: 2882-2889.

GiBBS S.P. 1981. The chloroplasts of some algal groups may have evolved from endosymbiotic eukaryotic algae. Annals of the New York Academy of Sciences 361: 193-208.

GiBBS S.P. 1993. The origin of algal chloroplasts. In: Origins of plastids (Ed. by R.A. Lewin), pp. 107-121. Chapman \& Hall, New York and London.

Giovannoni S.J., Wood N. \& Huss V.A.R. 1992. Molecular phylogeny of oxygenic cells and organelles based on small-subunit ribosomal RNA sequences. In: Origins of plastids (Ed. by R.A. Lewin), pp. 159-170. Chapman \& Hall, New York and London.

Huss V.A.R. \& JAHNKE K.-D. 1994. DNA base modification in Chlorella. European Journal of Phycology 29: 87-92.

Huss V.A.R., Dörr R. Grossmann U. \& Kessler E. 1986. Deoxyribonucleic acid reassociation in the taxonomy of the genus Chlorella. I. Chlorella sorokiniana. Archives of Microbiology 145: 329-333.

Huss V.A.R., Wein K.H. \& Kessler E. 1988. Deoxyribonucleic acid reassociation in the taxonomy of the genus Chlorella. IV. Chlorella protothecoides and its relationship to the genus Prototheca. Archives of Microbiology 150: 509-511.

JEFFREY S.W. 1989. Chlorophyll $c$ pigments and their distribution in the chromophyte algae. In: The chromophyte algae: problems and perspectives (Ed. by J.C. Green, B.S.C. Leadbeater \& W.L. Diver), pp. 13-36. Clarendon Press, Oxford. 
Kowallik K.V. 1992. Origin and evolution of plastids from chlorophyll a + c-containing algae: suggested ancestral relationships to red and green algal plastids. In: Origins of plastids (Ed. by R.A. Lewin), pp. 223-263. Chapman \& Hall, New York and London.

Kowallik K.V., Stoebe B., Schaffran I., Kroth-Pancic P. \& Freier U. 1995. The chloroplast genome of a chlorophyll a + c-containing alga, Odontella sinensis. Plant Molecular Biology Reports 13: 336-342.

Li W.-H. 1997. Molecular evolution. Sinauer Associates, Sunderland, MA. 487 $\mathrm{pp}$

Margulis L. 1981. Symbiosis in cell evolution. Freeman, San Francisco. 419 pp.

MARmur J. 1961. A procedure for the isolation of deoxyribonucleic acid from microorganisms. Journal of Molecular Biology 3: 208-218.

Martin W., Stoebe B., Goremykin V., Hansmann S., Hasegawa M. \& Kowallik K.V. 1998. Gene transfer to the nucleus and the evolution of chloroplasts. Nature 393: 162-165.

Matassi G., Sharp P.M. \& Gautier C. 1999. Chromosomal location effects on gene sequence evolution in mammals. Current Biology 9: 786-791.

McFadden G.I. \& WALler R.F. 1997. Plastids in parasites of humans. Bioessays 19: $1033-1140$.

Medlin L.K., Kooistra W.H.C.F., Potter D., Saunders G.W. \& Andersen R.A. 1997. Phylogenetic relationships of the 'golden algae' (haptophytes, heterokont chromophytes) and their plastids. Plant Systematics and Evolution, supplement 11: 187-219.

MereschKowsky C. 1905. Über Natur und Ursprung der Chromatophoren im Pflanzenreiche. Biologisches Centralblatt 25: 593-604.

Moreira D., Le Guyader H. \& Philippe H. 2000. The origin of red algae and the evolution of chloroplasts. Nature 405: 69-72.

MÜLler W. \& GAUTIER F. 1975. Interactions of heteroaromatic compounds with nucleic acids. A*T-specific non-intercalating DNA ligands. European Journal of Biochemistry 54: 385-394.
Sáez et al.: Plastid genome size in Ochrosphaera

Raven P.H. 1970. A multiple origin for plastids and mitochondria. Science 169: $641-646$

Rowan K.S. 1989. Photosynthetic pigments of algae. Cambridge University Press, Cambridge. 334 pp.

Scaramuzzi C.D., Stokes H.W. \& Hiller R.G. 1992. Heat shock Hsp70 protein is chloroplast-encoded in the chromophytic alga Pavlova lutherii. Plant Molecular Biology 18: 467-476.

SCHIMPER A.F.W. 1883. Über die Entwicklung der Chlorophyllkörner und Farbkörner. Botanische Zeitung 41: 105-114.

Sugiura M., Hirose T. \& Sugita M. 1998. Evolution and mechanism of translation in chloroplasts. Annual Review in Genetics 32: 437-459.

Tengs T., Dahlberg O.J., Shalchian-Tabrizi K., Klaveness D., Rudi K., Delwiche C.F. \& JaKobsen K.S. 2000. Phylogenetic analyses indicate that the 19'hexanoyloxy-fucoxanthin-containing dinoflagellates have tertiary plastids of haptophyte origin. Molecular Biology and Evolution 17: 718-729.

TiETZE A. 1996. Molekulare Charakterisierung der rRNA- und atp-Gencluster auf dem Plastiden-Genom von Ochrosphaera neapolitana. Thesis, Friedrich-Alexander-University of Erlangen-Nuremberg, Germany.

Valentin K. \& Zetsche K. 1990. Rubisco genes indicate a close phylogenetic relation between the plastids of Chromophyta and Rhodophyta. Plant Molecular Biology 15: 575-584.

Valentin K., Cattolico R.A. \& Zetszche K. 1992. Phylogenetic origin of the plastids. In: Origins of plastids (Ed. by R.A. Lewin), pp. 193-221. Chapman \& Hall, New York and London.

Wetmur J.G. \& DAVIDSON N. 1968. Kinetics of renaturation of DNA. Journal of Molecular Biology 31: 349-370.

Zhang Z., Green B.R. \& Cavalier-Smith T. 1999. Single gene circles in dinoflagellate chloroplast genomes. Nature 400: 155-159.

Accepted 10 February 2001 